Case Reports
in Dermatology
Case Rep Dermatol 2020;12:124-131

DOI: 10.1159/000509994

Published online: July 29, 2020
(C) 2020 The Author(s)

Published by S. Karger AG, Basel

www.karger.com/cde

This article is licensed under the Creative Commons Attribution-NonCommercial 4.0 International License (CC BY-NC) (http://www.karger.com/Services/OpenAccessLicense). Usage and distribution for commercial purposes requires written permission.

\title{
Unexpected Presentation of COVID- 19 in a 38-Year-Old Male Patient: A Case Report
}

\author{
Narges Malih ${ }^{a}$ Ghazal Hajinasrollah $^{b} \quad$ Marjan Zare $^{b}$ \\ Mahboobeh Taherib
}

aSocial Determinants of Health Research Center, Shahid Beheshti University of Medical Sciences, Tehran, Iran; ${ }^{\text {b}}$ Department of Community Medicine, Shahid Beheshti University of Medical Sciences, Tehran, Iran

\section{Keywords}

COVID-19 $\cdot$ SARS-COV-2 $\cdot$ Rash $\cdot$ Infections

\section{Abstract}

We presently report the case of COVID-19 in a 38-year-old male who had come to the primary health care clinic of Shahid Beheshti University of Medical Sciences, which specializes in the COVID-19 epidemic. He reported having fatigue, myalgia, fever, rash, and loss of taste and smell. The physical findings were maculopapular rash over his trunk, inguinal regions, and left arm, erythema of larynx with an aphthous lesion on left tonsil, he did not have a fever, and respiratory distress symptoms. There were no changes regarding COVID-19 in the spiral lung CT scan. However, the result of PCR for COVID-19 RNA was positive.

\section{(C) 2020 The Author(s)}

Published by S. Karger AG, Basel 


\section{Case Reports in Dermatology}

Case Rep Dermatol 2020;12:124-131

DOI: 10.1159/000509994

(c) 2020 The Author(s). Published by S. Karger AG, Basel www.karger.com/cde

Malih et al.: Unexpected Presentation of COVID-19 in a 38-Year-Old Male Patient: A Case Report

\section{Introduction}

COVID-19 is an infectious disease caused by the recently discovered SARS-CoV-2. This new virus and infection were found in the outbreak in Wuhan, China, in December 2019. The most common symptoms of COVID-19 are fever, tiredness, and dry cough. Some patients may have aches and pains, nasal congestion, runny nose, sore throat, or diarrhea. These symptoms are usually mild and begin gradually [1]. About $80 \%$ of patients recover from the disease without needing special treatment. Older people, and those with underlying medical problems such as high blood pressure, heart problem, or diabetes, are more likely to develop severe illness and may even present severe acute respiratory syndrome [2].

We report a case of COVID-19 infection in Iran with pharyngeal swabs tested positive by Real-Time Reverse Transcriptase (RT)-PCR Diagnostic Panel assay who had a maculopapular rash and aphthous lesion on the tonsil.

\section{Case Report}

A 38-year-old male, who had come to the primary health care clinic of Shahid Beheshti University of Medical Sciences, which is specialized in the COVID-19 epidemic, with a chief complaint of a rash on the third day of his illness. He said, the very first day, he felt fatigued and myalgia, and the second day he found low-grade fever.

On physical exam, he was stable, his axillary temperature was $36.5^{\circ} \mathrm{C}$, respiratory rate was 16 , pulse rate was 84 , and $\mathrm{O}_{2}$ saturation was $96 \%$. Moreover, there were maculopapular rashes in his inguinal regions. He did not have any symptoms of upper or lower respiratory tract infection.

We performed hematology and serology tests. Also, we ordered spiral lung CT scan in suspicions of COVID-19.

On the fourth day, he returned with the result of hematology and serology tests and spiral lung CT scan. He claimed that the rash had progressed, and the sore throat had added to his symptoms.

On the laryngeal examination, we found erythema and an aphthous lesion on the left tonsil (Fig. 1); also, we found maculopapular rashes on all over his trunk, left arm and inguinal region (Fig. 2). Hematology and C-reactive protein (CRP) tests were regular (Table 1); also, spiral lung CT scan was normal (Fig. 3).

We prescribed him acetaminophen to reduce his pain, offered him to drink plenty of water, rest well, and keep the social distance from others.

On the follow-up, on the fifth day we called him, he added he had lost his sense of smell and taste. Meanwhile, his wife had the same symptoms. Therefore, we asked him to come to our clinic to carry out a pharyngeal swabs test for the RT-PCR Diagnostic Panel assay.

On the sixth day, we performed a PCR test. After 2 days, the result of the pharyngeal swab for SARS-CoV-2 was positive. 


\section{Case Reports in Dermatology}

Case Rep Dermatol 2020;12:124-131

DOI: $10.1159 / 000509994$

(C) 2020 The Author(s). Published by S. Karger AG, Basel www.karger.com/cde

Malih et al.: Unexpected Presentation of COVID-19 in a 38-Year-Old Male Patient: A Case Report

\section{Discussion}

Our case is the first case of confirmed COVID-19 disease with cutaneous presentations in Iran. Along with our finding, there had been cases of the COVID-19 disease with cutaneous manifestations in other countries, including China and Italy. The first report of cutaneous involvement was published in a study by Guan et al. [1] in China, which included skin rash development in $2(0.2 \%)$ patients out of 1,099 confirmed cases of COVID-19. The cutaneous manifestations of COVID-19 cases in Recalcati [3] in Italy were reported in three forms in 18 cases out of 88 confirmed COVID-19 patients, an erythematous rash in 14, widespread urticaria in 3 and varicella-like vesicles in 1 patient. Another study in Italy reported skin manifestation of COVID-19 patients in 16 out of 22 confirmed cases. Systemic symptoms to exanthem median latency time was 3 days; the median duration of cutaneous symptoms was 8 days; vesicles were the predominant lesion in 12 (54.5\%) of the patients. The trunk was involved continuously, and there was no fascial or mucosal involvement. The most common systematic symptoms included fever, cough, headache, weakness, coryza, and dyspnea. Hypogeusia was reported in 4 (18.2\%) of the patients [4]. As we mentioned, our patient had an aphthous ulcer on the left tonsil, which had not been reported in the Italian studies.

Two COVID-19 patients with a dengue-like petechial rash had been reported in Thailand and Spain $[5,6]$. In the current study, we found a maculopapular rash instead of petechial lesions.

Although in our study the chest CT was normal, in a case report in France a 64-year-old woman with type 2 diabetes had an abnormal chest CT along with fever $\left(40^{\circ} \mathrm{C}\right)$, asthenia, and erythematous rash on both antecubital fossae, which extended on the trunk and axillary folds. RT-PCR test on a nasopharyngeal swab specimen was positive for COVID-19 [7].

In our study, the patient had normal blood lymphocyte count. There was a 27-year-old woman with an urticarial eruption who was tested positive for COVID-19 (PCR SARS-CoV-2) and lymphopenia in France [8].

Although we did not find any lesion at acral areas, red-purple papules on acral areas in 2 RT-PCR-confirmed COVID-19 patients had been reported in Kuwait and a 13-year-old boy in Italy $[9,10]$.

Another confirmed case of COVID-19 with confluent erythematous-yellowish papules in both heels was reported in a 28-year-old woman in Spain who also had diarrhea [11]. In our patient, there were no gastrointestinal manifestations, including diarrhea.

Two Caucasian COVID-19 patients with transient unilateral livedo reticularis eruption on their legs had been reported in a study by Manalo et al. [12] in the United States. But this manifestation was not seen in our patient.

Along with the importance of skin lesions as a manifestation of COVID-19 infection, viral exanthem due to concurrent viral infection and drug eruption resulting from a hypersensitivity reaction to azithromycin should be taken into account [13]. Among differential diagnoses for a tonsillar aphthous lesion, herpes esophagitis should be considered, which mostly occurs in people with a compromised immune system as a result of another more serious condition like cancer or HIV/AIDS. The symptoms include throat and chest pain, along with irritation and inflammation of the throat. The lesions are limited to the pharyngeal area, which is in contrast to our patient, who reported maculopapular rashes in his inguinal region [14]. 


\section{Case Reports in Dermatology}

Case Rep Dermatol 2020;12:124-131

DOI: $10.1159 / 000509994$

(C) $202-131$

(C) 2020 The Author(s). Published by S. Karger AG, Basel www.karger.com/cde

Malih et al.: Unexpected Presentation of COVID-19 in a 38-Year-Old Male Patient: A Case Report

With the rising number of cases with different dermatological manifestations, there had been a raised awareness in health care providers to consider COVID-19 infection as a cause of skin complaints of the patients [15]. In cases with generalized rashes, different diagnoses should be regarded as such as drug reactions, bacterial or viral infections, allergies, and autoimmune response along with COVID-19 disease [16]. On 19 February 2020, first confirmed cases of COVID-19 infections were reported in Qom, Iran. As the second country in Asia which struggles with COVID-19 epidemic in case of the time of onset of an outbreak after China, the second rank in case of total COVID-19 confirmed cases after Turkey and the first rank in Eastern Mediterranean region [17], it is essential to take into account cutaneous manifestations of COVID-19 to manage the contacts of infected cases and treatment of patients with severe clinical presentations.

\section{Acknowledgment}

A special gratitude we give to Vice-Chancellor for Health Affairs of Shahid Beheshti University of Medical Sciences, whose contribution in stimulating suggestions and encouragement, helped us to join to primary health care clinic of Shahid Beheshti University of Medical Sciences, which is specialized for COVID-19 epidemic and made us have unique experiences on COVID-19 disease.

\section{Statement of Ethics}

Our patient has given his written informed consent to publish his case (including publication of images). Also, the study protocol was approved by the institute's committee on human research of Shahid Beheshti University of Medical Sciences. Moreover, the research was conducted ethically in accordance with the World Medical Association Declaration of Helsinki.

\section{Conflict of Interest Statement}

The authors have no conflicts of interest to declare.

\section{Funding Sources}

We are not being funded.

\section{Author Contributions}

Ghazal Hajinasrollah and Narges Malih conceived of the presented idea. Ghazal Hajinasrollah developed the theory and performed the computations. Marjan Zare and Mahboobeh Taheri verified the analytical methods. Narges Malih encouraged Ghazal 


\section{Case Reports in Dermatology}

Case Rep Dermatol 2020;12:124-131

DOI: $10.1159 / 000509994$

(C) 2020 The Author(s). Published by S. Karger AG, Basel www.karger.com/cde

Malih et al.: Unexpected Presentation of COVID-19 in a 38-Year-Old Male Patient: A Case Report

Hajinasrollah to investigate and supervised the findings of this work. All authors discussed the results and contributed to the final manuscript. Ghazal Hajinasrollah and Narges Malih carried out the experiment. Ghazal Hajinasrollah and Narges Malih wrote the paper with support from Marjan Zare and Mahboobeh Taheri.

Both Marjan Zare and Mahboobeh Taheri contributed to the final version of the manuscript. Narges Malih supervised the project.

\section{References}

1 Guan W, Ni Z, Hu Y, Liang W, Ou C, He J, et al. Clinical Characteristics of Coronavirus Disease 2019 in China. N Engl J Med. 2020 Apr 30;382(18):1708-20.

2 Q\&A on coronaviruses (COVID-19) [Internet]. World Health Orgnisation. 2020 [cited 2020 Apr 26]. Available from: https://www.who.int/news-room/q-a-detail/q-a-coronaviruses.

3 Recalcati S. Cutaneous manifestations in COVID-19: a first perspective. J Eur Acad Dermatol Venereol. 2020 May;34(5):e212-3.

4 Marzano AV, Genovese G, Fabbrocini G, Pigatto P, Monfrecola G, Piraccini BM, et al. Varicella-like exanthem as a specific COVID-19-associated skin manifestation: multicenter case series of 22 patients. J Am Acad Dermatol. 2020 Jul;83(1):280-5.

5 Joob B, Wiwanitkit V. COVID-19 can present with a rash and be mistaken for dengue. J Am Acad Dermatol. 2020 May;82(5):e177.

6 Jimenez-Cauhe J, Ortega-Quijano D, Prieto-Barrios M, Moreno-Arrones OM, Fernandez-Nieto D. Reply to "COVID-19 can present with a rash and be mistaken for dengue": petechial rash in a patient with COVID-19 infection. J Am Acad Dermatol. 2020 Apr;S0190-9622(20)30556-9.

7 Mahé A, Birckel E, Krieger S, Merklen C, Bottlaender K. A distinctive skin rash associated with coronavirus disease 2019? J Eur Acad Dermatol Venereol. 2020 Jun;34(6):e246-7.

8 Henry D, Ackerman M, Sancelme E, Finon A, Esteve E. Urticarial eruption in COVID-19 infection. Eur Acad Dermatol Venereol. 2020 Jun;34(6):e244-5.

9 Alramthan A, Aldaraji W. Two cases of COVID-19 presenting with a clinical picture resembling chilblains: first report from the Middle East. Clin Exp Dermatol. 2020 Aug;45(6):746-8.

10 Mazzotta F, Troccoli T. Acute acro-ischemia in the child at the time of COVID-19. Eur J Pediat Dermatol 2020;30(2):71-4.

11 Estébanez A, Pérez-Santiago L, Silva E, Guillen-Climent S, García-Vázquez A, Ramón MD. Cutaneous manifestations in COVID-19: a new contribution. J Eur Acad Dermatol Venereol. 2020 Jun;34(6):e250-1.

12 Manalo IF, Smith MK, Cheeley J, Jacobs R. A Dermatologic Manifestation of COVID-19: Transient Livedo Reticularis. J Am Acad Dermatol. 2020 Jan.

13 Najarian DJ. Morbilliform Exanthem Associated with COVID-19. JAAD Case Rep. 2020 Apr;6(6):493-4.

14 The Throat [accessed 2020 Jun 26]. Available from: https://www.stdaware.com/stds/herpes-in-the-throatesophagitis.

15 covidprotocols.org. [Internet]. Available from: https://covidprotocols.org/protocols/dermatology/

16 Ely JW, Seabury Stone M. The generalized rash: part I. Differential diagnosis. Am Fam Physician. 2010 Mar;81(6):726-34.

17 World Health Orgnisation. Coronavirus disease 2019 (COVID-19) Situation Report - 94 Data. 23 April 2020. 2020. 
Case Reports
in Dermatology

Case Rep Dermatol 2020;12:124-131

DOI: $10.1159 / 00050999$

(C) 2020 The Author(s). Published by S. Karger AG, Basel www.karger.com/cde

Malih et al.: Unexpected Presentation of COVID-19 in a 38-Year-Old Male Patient: A Case Report

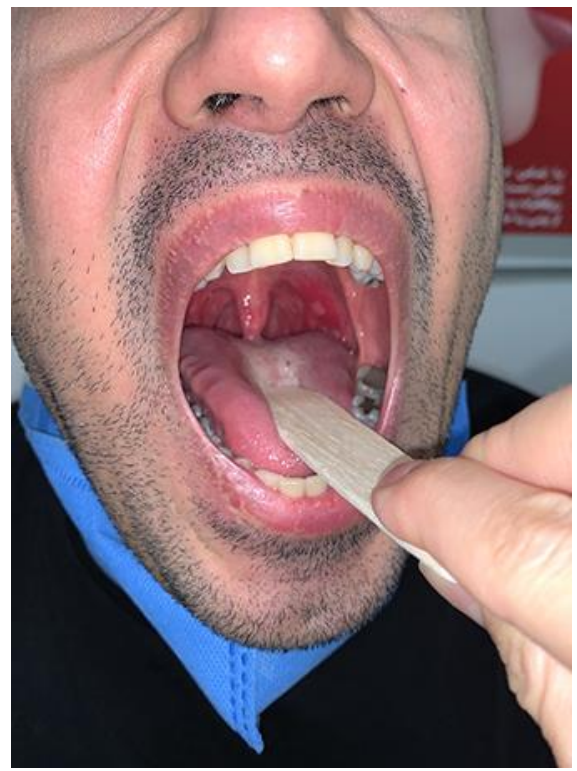

Fig. 1. Erythema and aphthous lesion on the left tonsil.

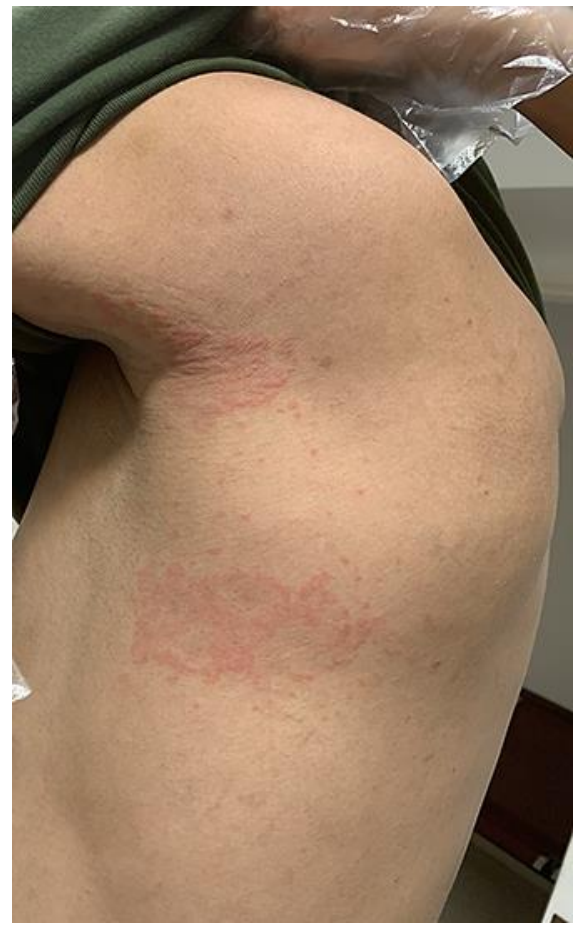

Fig. 2. Maculopapular rash on trunk. 
Case Reports
in Dermatology

Case Rep Dermatol 2020;12:124-131

DOI: $10.1159 / 000509994$

(C) 2020 The Author(s). Published by S. Karger AG, Basel www.karger.com/cde

Malih et al.: Unexpected Presentation of COVID-19 in a 38-Year-Old Male Patient: A Case Report

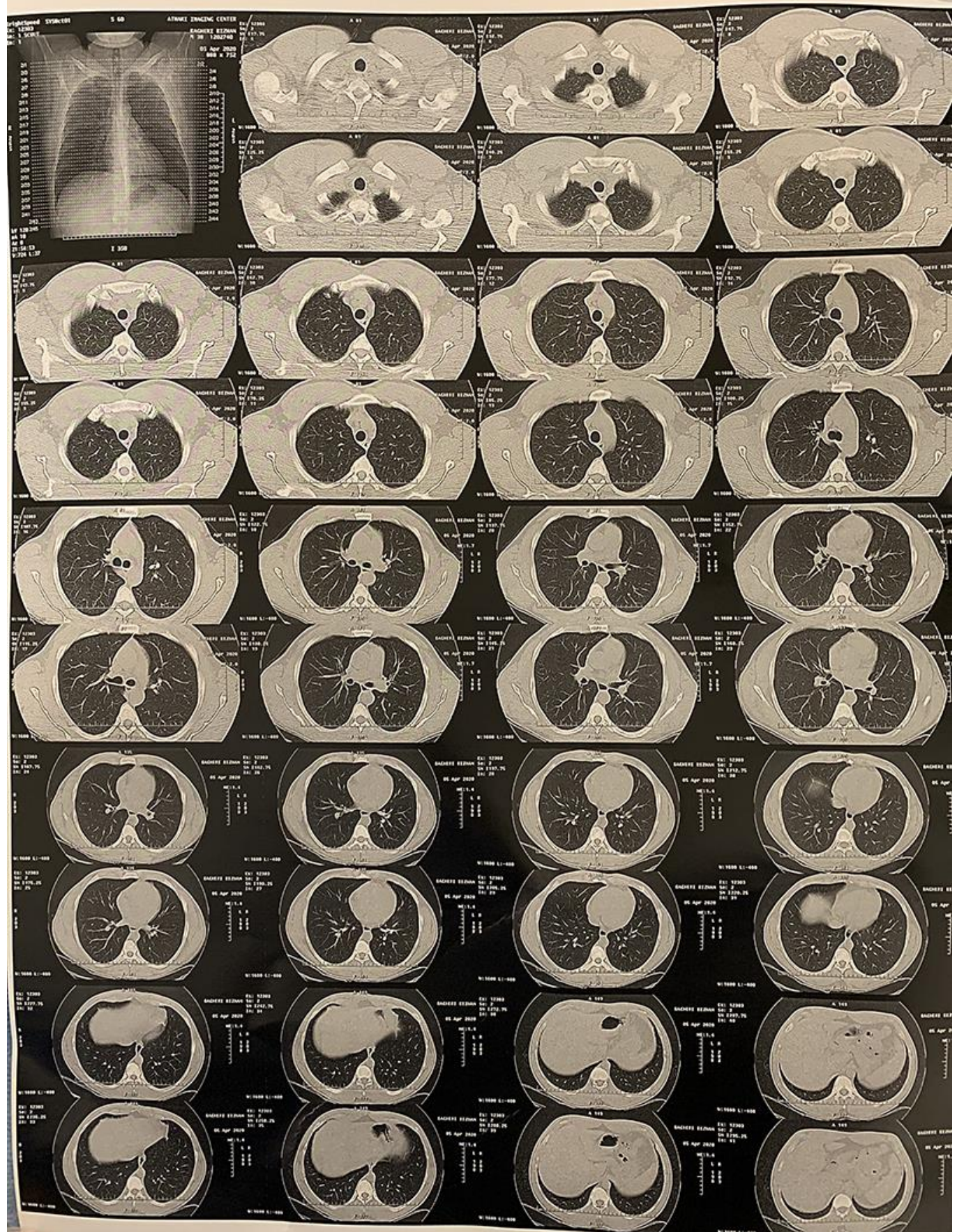

Fig. 3. Spiral lung CT scan. 
Case Reports in Dermatology
Case Rep Dermatol 2020;12:124-131

DOI: $10.1159 / 000509994$

(C)

(C) 2020 The Author(s). Published by S. Karger AG, Basel www.karger.com/cde

Malih et al.: Unexpected Presentation of COVID-19 in a 38-Year-Old Male Patient: A Case Report

Table 1. Complete blood count and C-reactive protein tests result

\begin{tabular}{|c|c|c|c|c|c|}
\hline $\mathrm{CBC}$ & Result & Rechecked Unit & Reference range & Differential & \\
\hline \multicolumn{6}{|l|}{ Hematology } \\
\hline WBC & 5.0 & $\times 10^{3} / \mathrm{micl}$ & & Neutrophils & 63.6 \\
\hline $\mathrm{RBC}$ & 4.93 & & & Lymphocytes & 32.6 \\
\hline Hemoglobin & 15.4 & $\mathrm{~g} / \mathrm{dL}$ & $12-16$ & Monocytes & 3.5 \\
\hline Hematocrit & 43.1 & $\%$ & $36-51$ & Eosinophils & 0.2 \\
\hline MCV & 87.4 & FL & & Basophils & 0.1 \\
\hline $\mathrm{MCH}$ & 31.2 & pg & & Total & $100 \%$ \\
\hline $\mathrm{MCHC}$ & 35.7 & $\mathrm{~g} / \mathrm{dL}$ & & & \\
\hline Platelets & 158 & $\times 10^{3} / \mathrm{micl}$ & $150-400$ & & \\
\hline Test & Result & Rechecked Unit & Reference range & & \\
\hline \multicolumn{6}{|l|}{ Blood serology } \\
\hline C-reactive protein & 0.5 & $\mathrm{mg} / \mathrm{dL}$ & $0-0.6$ & & \\
\hline
\end{tabular}

